\title{
Combining targeted therapeutics in the era of precision medicine
}

\author{
D Papadatos-Pastos ${ }^{1,2}$, M J De Miguel Luken ${ }^{1,2}$ and Timothy A Yap*,1,2 \\ ${ }^{1}$ Division of Clinical Studies, The Institute of Cancer Research, Sutton, Surrey, UK and ${ }^{2}$ Drug Development Unit, Royal Marsden \\ NHS Foundation Trust, Sutton, Surrey, UK
}

We have now entered the era of precision medicine, armed with an armamentarium of novel antitumour agents against a range of critical oncogenic drivers (Tsimberidou et al, 2014). Although there have been noteworthy successes, patient benefit with single agent targeted therapies has been generally modest (Yap et al, 2013). The reasons for this are multifactorial and well described; they include the disruption of feedback loops, development of crosstalk and other escape mechanisms observed with signalling pathway inhibitors, as well as other issues such as intratumoural heterogeneity. The co-development of investigational targeted agents is thus arguably one of the most important challenges in cancer medicine today.

In the article by Wilky and colleagues, the investigators present findings from a phase I study assessing the vertical blockade of MEK1/2 and insulin growth factor-1 receptor (IGF-1R) with the small molecule selumetinib (AstraZeneca, Macclesfield, UK) and monoclonal antibody cixutumumab (ImClone Systems Inc., Bridgewater, NJ, USA), respectively (Wilky et al, 2014). Both selumetinib and cixutumumab had modest antitumour activity as single agents, providing the impetus for this and other targeted combination strategies (Table 1) (Rothenberg et al, 2007; Banerji et al, 2010). To our knowledge, this is the first published trial of a combination involving IGF-1R and MEK inhibitors, which aims to minimise the effects of feedback loops that may lead to the development of drug resistance (Flanigan et al, 2013).

The authors should be commended for this well-conducted study involving two investigational agents from different pharmaceutical companies. The primary objectives of safety and tolerability were achieved, and the maximum tolerated combination dose was $50 \mathrm{mg}$ twice daily of selumetinib and $12 \mathrm{mg} \mathrm{kg}^{-1}$ of cixutumumab given every 2 weeks; these were also the starting doses of both drugs in this study. The single agent maximum tolerated dose (MTD) of selumetinib was previously established at $75 \mathrm{mg}$ twice daily, whereas cixutumumab monotherapy demonstrated safety at $15 \mathrm{mg} \mathrm{kg}^{-1}$ every 2 weeks (Rothenberg et al, 2007; Banerji et al, 2010). In view of the relatively high starting doses, it is not surprising that the combination MTD was established after a single dose escalation using a conventional $3+3$ phase I study design. Other phase I trial designs that could also be considered for such targeted combination studies include a bidirectional-dosing plan, determined by a rule-based up-and-down design (Gandhi et al, 2014). This could potentially lead to the identification of two different MTDs: a selumetinib-high and/or a cixutumumab-high dose. Alternatively, model-based designs that use statistical models to establish a dose-outcome relationship to guide the dose-finding process may also be pursued (Mandrekar, 2014). Such a modelbased strategy enables more patients to be treated at doses closer to the MTD, reducing the number of patients required on study. Intra-patient dose escalation of one or both drugs in all patients is another combination strategy that could be considered (Yap et al, 2013).

The DLTs of ophthalmic symptoms in two of seven patients treated at the second dose level, and ophthalmic adverse events in $40 \%$ of patients were likely to be a manifestation of the welldescribed selumetinib-related mechanism-based ocular toxicities (Banerji et al, 2010). Other important adverse events observed with this combination include rash (77\%), mucositis (53\%), gastrointestinal symptoms and hyperglycaemia. Although not DLTs, such toxicities may ultimately limit the chronic use of these drugs in combination and impact patient benefit in late phase clinical trials.

Although the single agent MTD of selumetinib was not reached in this trial, data from the monotherapy study suggest that the dose of $50 \mathrm{mg}$ twice daily is biologically active (Banerji et al, 2010). In addition, Wilky and colleagues report a correlation between the plasma drug PK levels and decreases in tumour ERK and S6 phosphorylation by immunohistochemistry, albeit in a small number of patients. Although the suppression of phosphorylated S6 in post-treatment tumour biopsies may indicate that the PI3KAKT pathway was potentially modulated, S6 phosphorylation is not a direct readout of IGF-1R inhibition, in contrast to other markers such as IGF-1R expression or total and free IGF-1 (Larsson et al, 2007). It would also have been interesting to conduct detailed biomarker studies to evaluate the effects of the combination treatment on feedback loops along the IGF-1R-MEK signalling axis. 
Table 1. Cixutumumab and selumetinib clinical trials in combination with other targeted therapies

\begin{tabular}{|c|c|c|c|c|c|c|c|}
\hline Trial & Phase & Compounds & Tumour type & Pts & End point & Results & Toxicities \\
\hline \multicolumn{8}{|l|}{ Cixutumumab } \\
\hline $\begin{array}{l}\text { Schwartz GK } \\
\text { NCT01016015 } \\
\text { The Lancet } 2013\end{array}$ & II & CX-temsirolimus & $\begin{array}{l}\text { Bone and soft } \\
\text { tissue sarcoma }\end{array}$ & 174 & $\begin{array}{l}\text { PFS at } 12 \\
\text { weeks }\end{array}$ & $33 \%$ & $\begin{array}{l}\text { Anaemia }(9 \%), \text { HG }(10 \%), \\
\text { hypophosphataemia }(9 \%) \\
\text { lymphopenia (14\%) and mucositis (11\%) }\end{array}$ \\
\hline $\begin{array}{l}\text { Glisson BS } \\
\text { NCT00617734 } \\
\text { ASCO } 2013\end{array}$ & $\|$ & $\begin{array}{l}\text { CX vs CX plus } \\
\text { cetuximab }\end{array}$ & R/M-SCCHN & 97 & PFS & $1.9 \mathrm{~m}$ vs $2.0 \mathrm{~m}$ & $\begin{array}{l}\text { Fatigue }(61.4 \%) \text {, rash }(63.6 \%) \text {, nausea } \\
(34 \%) \text {, weight decreased }(29.5 \%) \text {, } \\
\text { HG }(29.5 \%) \text { and vomiting }(20.5 \%)\end{array}$ \\
\hline $\begin{array}{l}\text { Wagner LM } \\
\text { NCT01614795 } \\
\text { ASCO } 2014\end{array}$ & $\|$ & $\begin{array}{l}\text { CX plus } \\
\text { temsirolimus }\end{array}$ & $\begin{array}{l}\text { Paediatric } \\
\text { patients with } \\
\text { relapsed } \\
\text { sarcoma }\end{array}$ & 43 & $\begin{array}{l}\text { Response } \\
\text { rate }\end{array}$ & $\begin{array}{l}\text { No objective } \\
\text { response }\end{array}$ & $\begin{array}{l}\text { Mucositis, electrolyte disturbances and } \\
\text { myelosuppression }\end{array}$ \\
\hline $\begin{array}{l}\text { Weickhardt A } \\
\text { NCT00778167 } \\
\text { J Thorac Oncol } 2012\end{array}$ & $|/| \mid$ & CX-erlotinib & NSCLC & 18 & $\begin{array}{l}\text { Safety and } \\
\text { antitumour } \\
\text { effect }\end{array}$ & $\begin{array}{l}\text { Tolerable. } \\
5 \text { pts stable } \\
\text { disease }\end{array}$ & Rash and fatigue \\
\hline $\begin{array}{l}\text { Naing A } \\
\text { NCT00678769 } \\
\text { Br J Cancer } 2013\end{array}$ & I (exp) & CX-temsirolimus & $\begin{array}{l}\text { Adrenocortical } \\
\text { carcinoma }\end{array}$ & 26 & $\begin{array}{l}\text { Safety and } \\
\text { antitumour } \\
\text { effect }\end{array}$ & \begin{tabular}{|l|} 
Well \\
tolerated, \\
$>40 \%$ \\
prolonged SD
\end{tabular} & $\begin{array}{l}\text { TC }(38 \%) \text {, mucositis }(58 \%) \text {, } \\
\text { hypercholesterolaemia (31\%), } \\
\text { hypertriglyceridaemia (35\%) } \\
\text { and HG (31\%) }\end{array}$ \\
\hline $\begin{array}{l}\text { Naing A } \\
\text { NCT00678769 } \\
\text { Clin Cancer Res. } 2012\end{array}$ & I (exp) & CX-temsirolimus & Ewing's sarcoma & 20 & $\begin{array}{l}\text { Safety and } \\
\text { antitumour } \\
\text { effect }\end{array}$ & $\begin{array}{l}35 \% \mathrm{SD}, \mathrm{PR} \\
\text { or } \mathrm{CR}\end{array}$ & $\begin{array}{l}\text { TC }(85 \%) \text {, mucositis }(8 \%), \\
\text { hypercholesterolaemia }(75 \%) \text {, } \\
\text { hypertriglyceridaemia }(70 \%) \\
\text { and HG (65\%) }\end{array}$ \\
\hline $\begin{array}{l}\text { Ma CX } \\
\text { NCT00699491 }\end{array}$ & 1 & CX-temsirolimus & Breast cancer & 26 & MTD & $15 \% \mathrm{SD}$ & Mucositis, neutropenia and TC \\
\hline $\begin{array}{l}\text { Breast Cancer Res Treat. } 2013 \\
\text { El-Khoueiry AB } \\
\text { NCT01008566 } \\
\text { ASCO } 2014\end{array}$ & I & CX-sorafenib & $\begin{array}{l}\text { Hepatocellular } \\
\text { carcinoma }\end{array}$ & 21 & $\begin{array}{l}\text { Safety, } \\
\text { MTD }\end{array}$ & OS 13.1 & $\begin{array}{l}\text { HG }(10 \%) \text {, diarrhoea }(19 \%), \\
\text { hypertension (19\%), TC (14\%), } \\
\text { palmar-plantar erythrodysesthesia (10\%) } \\
\text { and fatigue }(10 \%)\end{array}$ \\
\hline \multicolumn{8}{|l|}{ Selumetinib } \\
\hline $\begin{array}{l}\text { Ko AH } \\
\text { NCT01222689 } \\
\text { ASCO } 2013\end{array}$ & II & S-erlotinib & $\begin{array}{l}\text { Pancreatic } \\
\text { cancer }\end{array}$ & 46 & OS & $\begin{array}{l}\text { OS } 7.5 \mathrm{~m} \\
\text { PFS } 2.6 \mathrm{~m}\end{array}$ & $\begin{array}{l}\text { Rash (21\%), hypertension (13\%), } \\
\text { anaemia }(11 \%) \text {, diarrhoea (9\%) } \\
\text { and emesis }(9 \%)\end{array}$ \\
\hline $\begin{array}{l}\text { Carter CA } \\
\text { NCT01229150 } \\
\text { ASCO } 2013\end{array}$ & $\|$ & $\begin{array}{l}\text { S-erlotinib vs } \\
\text { erlotinib }\end{array}$ & NSCLC & 78 & $\begin{array}{l}\text { KRAS wt: } \\
\text { PFS }\end{array}$ & $\begin{array}{l}2.3 \mathrm{~m} \text { vs } \\
2.1 \mathrm{~m}, \mathrm{NS}\end{array}$ & $\begin{array}{l}\text { Diarrhoea }(23 \%) \text {, fatigue }(23 \%), \\
\text { lymphopenia }(13 \%) \text {, myositis }(10 \%), \\
\text { dyspnoea }(10 \%) \text { and rash }(7 \%)\end{array}$ \\
\hline & & & & & $\begin{array}{l}\text { KRAS mut: } \\
\text { ORR }\end{array}$ & $0 \%$ vs $7 \%$, NS & \\
\hline NCT01206140 & $\|$ & $\begin{array}{l}\text { S-temsirolimus } \\
\text { vs S }\end{array}$ & $\begin{array}{l}\text { Soft tissue } \\
\text { sarcoma }\end{array}$ & 70 & PFS & Ongoing & \\
\hline NCT01519427 & ॥ & S-MK2206 & $\begin{array}{l}\text { BRAF V600- } \\
\text { mutant } \\
\text { melanoma }\end{array}$ & NA & $\begin{array}{l}\text { Objective } \\
\text { response }\end{array}$ & NA & \\
\hline NCT01166126 & $\|$ & S-temsirolimus & $\begin{array}{l}\text { BRAF-mutant } \\
\text { melanoma }\end{array}$ & NA & $\begin{array}{l}\text { Objective } \\
\text { response }\end{array}$ & NA & \\
\hline $\begin{array}{l}\text { Dustin A } \\
\text { NCT01287130 }\end{array}$ & I & S-cetuximab & $\begin{array}{l}\text { Solid tumours } \\
\text { and KRAS- }\end{array}$ & 29 & $\begin{array}{l}\text { MTD, } \\
\text { tolerability }\end{array}$ & $\begin{array}{l}\text { Well } \\
\text { tolerated, }\end{array}$ & $\begin{array}{l}\text { Rash }(20 \%) \text {, hyponatraemia }(20 \%) \\
\text { and headache }(20 \%)\end{array}$ \\
\hline ASCO 2012 & & & & & & $2 \mathrm{PR}, 4 \mathrm{SD}$ & \\
\hline $\begin{array}{l}\text { Khan KH } \\
\text { NCT01021748 }\end{array}$ & I & S-MK2206 & Solid tumours & 51 & $\begin{array}{l}\text { MTD, } \\
\text { antitumour }\end{array}$ & Well & $\begin{array}{l}\text { Rash }(2 \%) \text {, stomatitis }(2 \%) \text { and detached } \\
\text { retinal pigment epithelium ( } 2 \%)\end{array}$ \\
\hline ASCO 2012 & & & & & effect & 3 PR, 24 SD & \\
\hline NCT01586624 & 1 & S-vandetanib & $\begin{array}{l}\text { Solid tumours } \\
\text { (esc) and NSCLC } \\
\text { (exp) }\end{array}$ & 48 & $\begin{array}{l}\text { MTD, } \\
\text { safety }\end{array}$ & Ongoing & \\
\hline NCT01364051 & $\|$ & S-cediranib & Solid tumours & 89 & MTD & Ongoing & \\
\hline
\end{tabular}

Only 9 of $30(30 \%)$ patients had BRAF mutation status available for this combination treatment involving a MEK inhibitor. In light of the multiple next-generation sequencing (NGS) technologies currently available in the clinic, should all patient tumours have been tested? In such a phase I trial involving patients with different cancers, context dependency between tumour types remains a critical issue. Nevertheless, for signal-searching phase I studies where biologically active doses of drugs are used in patients from the outset, it may be useful to use multiplexed targeted NGS platforms to investigate a range of 'hot-spot' mutations and other aberrations as putative predictive biomarkers of response and resistance. This is especially important when no analytically validated predictive biomarkers of response have been established for a combination treatment. There is certainly now an increased impetus to undertake such NGS studies in both sequential tumour and circulating plasma DNA specimens in early phase trials for retrospective correlation with antitumour responses. 
On the basis of the preliminary antitumour activity observed in this study, the investigators suggest head and neck squamous cell carcinoma, as well as thyroid and colorectal cancers as promising tumour types to explore. However, due to the limited sample size and antitumour responses in this study, it remains to be seen if these malignancies will truly represent ideal targets for this combination. An alternative molecularly-driven cancer to consider may be KRASmutant non-small cell lung carcinoma (NSCLC). The combination of IGF-1R and MEK inhibitors has been shown to enhance inhibition of KRAS-mutant cell lines and improve effectiveness in autochthonous mouse models of Kras-induced NSCLC, providing the rationale for this approach (Molina-Arcas et al, 2013).

In conclusion, selumetinib and cixutumumab appear to be a well tolerated and biologically active combination. In this age of precision medicine, the identification of both tumour types and molecular subtypes that are likely to benefit from the simultaneous blockade of IGF-1R and MEK with this novel combination now need to be urgently explored.

\section{REFERENCES}

Banerji U, Camidge DR, Verheul HM, Agarwal R, Sarker D, Kaye SB, Desar IM, Timmer-Bonte JN, Eckhardt SG, Lewis KD, Brown KH, Cantarini MV, Morris C, George SM, Smith PD, van Herpen CM (2010) The first-in-human study of the hydrogen sulfate (Hyd-sulfate) capsule of the MEK1/2 inhibitor AZD6244 (ARRY-142886): a phase I open-label multicenter trial in patients with advanced cancer. Clin Cancer Re. 16: 1613-1623.

Flanigan SA, Pitts TM, Newton TP, Kulikowski GN, Tan AC, McManus MC, Spreafico A, Kachaeva MI, Selby HM, Tentler JJ, Eckhardt SG, Leong S (2013) Overcoming IGF1R/IR resistance through inhibition of MEK signaling in colorectal cancer models. Clin Cancer Res 19: 6219-6229.

Gandhi L, Bahleda R, Tolaney SM, Kwak EL, Cleary JM, Pandya SS, Hollebecque A, Abbas R, Ananthakrishnan R, Berkenblit A, Krygowski M,
Liang Y, Turnbull KW, Shapiro GI, Soria JC (2014) Phase I study of neratinib in combination with temsirolimus in patients with human epidermal growth factor receptor 2-dependent and other solid tumors. J Clin Oncol 32: 68-75.

Larsson O, Girnita A, Girnita L (2005) Role of insulin-like growth factor 1 receptor signalling in cancer. Br J Cancer 2(12): 2007-2101.

Mandrekar SJ (2014) Dose-finding trial designs for combination therapies in oncology. J Clin Oncol 32: 65-67.

McKian KP, Haluska P. Cixutumumab (2009) Expert Opin Investig Drugs 18: 1025-1033.

Molina-Arcas M, Hancock DC, Sheridan C, Kumar MS, Downward J (2013) Coordinate direct input of both KRAS and IGF1 receptor to activation of PI3 kinase in KRAS-mutant lung cancer. Cancer Discov 3: 548-563.

Rothenberg M, Poplin E, Sandler A (2007) Phase I dose-escalation study of the anti-IGF-IR recombinant human IgG1 monoclonal antibody (Mab) IMC-A12, administered every other week to patients with advanced solid tumors (AACR-NCI-EORTC International Conference on Molecular Targets and Cancer Therapeutics) San Francisco, CA, USA.

Tsimberidou MD, PhD AM, Eggermont AM, Schilsky RL (2014) Precision cancer medicine: the future is now, only better. Am Soc Clin Oncol Educ Book 61-69.

Wilky BA, Rudek MA, Ahmed S, Laheru DA, Cosgrove D, Donehower RC, Nelkin B, Ball D, Doyle LA, Chen H, Ye X, Bigley G, Womack C, Azad NS (2014) A phase I trial of vertical inhibition of IGF signalling using cixutumumab, an anti-IGF-1R antibody, and selumetinib, an MEK 1/2 inhibitor, in advanced solid tumours; $\mathrm{Br} J$ Cancer 112(1): 24-31.

Yap TA, Omlin A, de Bono JS (2013) Development of therapeutic combinations targeting major cancer signaling pathways. J Clin Oncol 31: 1592-1605.

(c) (i) (2) This work is licensed under the Creative Commons AY NG SA Attribution-NonCommercial-Share Alike 3.0 Unported License. To view a copy of this license, visit http://creativecommons. org/licenses/by-nc-sa/3.0/ 